Article

\title{
How Levinas Can (and Cannot) Help Us with Political Apology in the Context of Systemic Racism
}

\author{
Brock Bahler \\ Department of Religious Studies, University of Pittsburgh, Pittsburgh, PA 15260, USA; bab145@pitt.edu
}

Received: 12 September 2018; Accepted: 16 November 2018; Published: 19 November 2018

\begin{abstract}
What is the structure of an apology? What is an apology supposed to achieve, and how do we know when it has achieved its purpose? These questions seem pretty straightforward when we are speaking of an apology as it is traditionally conceived, which considers an explicit action that I have performed toward another individual. But how does one apologize for one's thrownness into systemic structures of inequality and violence-such as America's long history of racism toward people of color? I call this here a "political apology," which may take both national forms—such as Australia's National "I'm Sorry Day"—or personal acts—such as when a white person might apologize to a friend who is a person of color for the persistence of anti-Black racism in America. This essay will consider Emmanuel Levinas's work and how it relates to this notion of a political apology. In some respects, Levinas's thought is profoundly constructive and useful; however, his ahistorical, asymmetrical account of intersubjectivity is inadequate to explain what an apology seeks to achieve on a substantial political level. For this, I believe we must articulate a Levinasian-inspired account of the self-other relation that more adequately takes into account both parties as well as the concrete situation in which the need for apology arises.
\end{abstract}

Keywords: Emmanuel Levinas; critical race theory; apology; empathy; intersubjectivity; ethics; systemic racism; social justice

\section{Introduction}

What is the structure of an apology? When is an apology meaningful? What is an apology supposed to achieve, and how do we know when it has achieved its purpose? The answers to these questions seem pretty straightforward when we are speaking of an apology as it is traditionally conceived, which considers an explicit action that I have performed toward another individual. But it is extremely narrow to limit one's responsibility to what one explicitly does or says to another person. Most of us live a life that exists because many others (whether human or animal) have died, or were exploited, so that we might breathe, eat, and live on the land. To use just one example that will be applicable to the theme of this essay, as a white male living in America, even if I never drove out the indigenous groups that once lived where I was born, never owned slaves, never promoted Jim Crow laws, and never verbally advocate for white supremacy, I am regularly a beneficiary of social structures that are grounded in centuries of prejudice and discrimination toward people of color. I find myself thrown into and complicit in the systemic power structures that perpetuate social inequalities, maintain racist systems of power, and feed racist stereotypes.

I find the history of white supremacy all around me, in my bones. One of my first ancestors who came to America settled in eastern Pennsylvania, fought in the Revolutionary War, and then moved to Virginia ... where he then proceeded to purchase his first eight slaves. I grew up attending both private and public schools where all of my teachers looked like me. As a professor, as I walk around the halls of my university, I find that the majority of those in power look like me. I find that the history 
of white supremacy affords me a sense of ease when I walk into philosophy conferences, with the sea of white bodies, with my familiarity of white ways of networking and speaking, and with the centuries-old assumption that white men are exemplars of universal rationality. And if I look closer, I find that the mythologies of white supremacy that make up years of my social training live inside me and are enacted through my unconscious habits and implicit biases.

This situation severely complicates the function and meaning of an apology. How does one respond to the guilt and shame one is exposed to when he or she comes face to face with this history of violence? How does one apologize for one's thrownness into systemic structures of institutionalized inequality? Is it even possible?

I call this here a "political apology," which may take both national or personal forms. For example, on the national level, what is the meaning of apology in Australia's annual "National I'm Sorry Day," which is a call to publicly acknowledge Australia's racist past, remember the Aboriginal children who were forcibly removed from their families, and promote policies that help "close the gap between Indigenous and non-Indigenous Australians" (Australian Government 2018) in areas such as life expectancy and education? To whom does one apologize when they register their general apology on a website for I'm Sorry Day? What kind of speech act is being performed here? What benefit does it have to the world?

There are many complicated problems with such public displays of apology. For one, they suggest that a rather simplistic, marginal solution-making an apology one day out of the year-can somehow mitigate centuries of systemic abuse, oppression, even genocide. It is not unlike the naïve and insensitive comments I have at times heard by white people in the United States, often entirely unfamiliar with America's history of systemic racism, such as: "We gave Martin Luther King Jr. a holiday, and made February 'Black History Month,' so what more could Black people want?" I have acquaintances who seem to believe they are active proponents of equality simply because they share a quotation by Dr. King on social media one day out of the year. If this is all that a national holiday asks of us in owning up to our country's extensive racist past, it is an embarrassing and offensive low bar.

Despite these pitfalls, I believe the spirit and motivation behind political apology is critically important. Establishing particular days in which we take a moment to remember the violence of our collective past is powerful and transformative as a society. Two main reasons come to mind on this point. First, the language of collective lament and mourning seems to have been largely lost in Western societies despite the fact that communal lament has been a practice in human civilization for centuries. We have been taught to ignore suffering, to not talk about pain and death. We have been largely taught to only celebrate the victories of the past. Yet the retrieval of this genre of speech can be a constructive mechanism for societies of diverse people to collectively bond, to acknowledge the suffering within the community, to admit that our failures have made us who we are just as much as our successes, and perhaps most of all, to honestly admit that we do not know how to solve the cycles of systemic injustice that are all around us. Second, as Martha Nussbaum notes, political celebrations, such as recognizing Martin Luther King Day, are a form of persuasion (Nussbaum 2013, p. 133). National holidays (not unlike holy days in religious traditions) are a means to instill certain sets of values into the community as a whole. And the rituals and practices associated with these holidays can be tools for the entire community to participate and live into these values and virtues.

We are somewhat familiar with these collective forms of apology, but for the purposes of this essay, I am actually going to bracket these official formulations. My focus will remain on the more peculiar, lesser observed personal forms of apologizing for systemic structures of injustice. What I have in mind is best illustrated by particular instances of it. For example, when Donald Trump became President of the United States, many of my white friends—-those who did not vote for Trump-took to Facebook to publicly apologize to their Black and Hispanic friends for what happened. What kind of apology is this? What does it seek to accomplish? Another example after Trump's election: a Black coworker or acquaintance, says to me: "He's your (white) president; he's not my president." To this, I feel compelled to say something. I'm compelled to defend myself ("I didn't vote for him!"). I'm compelled 
to apologize for how people of color bear the brunt of the current administration's policies. "I'm sorry." But what is happening in such a speech act? What does it seek to achieve, especially when the person I am speaking to resists my apology? Is it to make myself feel better, to expiate my white guilt? Am I merely seeking emotional catharsis, or do I really care about justice (Hackett 2017)?

Within this subfield of personal apologies, I am also bracketing what might be called insincere apologies, the "unapology." ${ }^{11}$ We are quite familiar with such apologies. The unapology is what we often hear from large corporations or famous individuals when they perform an act that is obviously racially tinged (whether sorely uninformed, on the one hand, or explicitly racist, on the other), and, in their public statement, perform a variety of verbal maneuvers ${ }^{2}$ to shift the blame (or even blame the victim!) and minimize what they did. The unapology is the kind of response we regularly hear from male celebrities when they have been called out for allegations regarding sexual harassment or assault (e.g., Kevin Spacey, Louis C.K., Mario Batali, Aziz Ansari, etc.). When the corporation Unilever, for example, created a Facebook ad for Dove body lotion, which depicted an African-American woman transforming into a white woman-the metamessage, then, is that use of a Dove product will wash away one's blackness, a mythos that has been promulgated for centuries-it responded to the backlash with an ambiguous unapology that the company had "missed the mark" (Slawson 2017). Most recently, on an individual level, Roseanne Barr offered an unapology after tweeting that former senior advisor to President Obama, Valerie Jarrett was the offspring of apes and Muslims. Then, her unapology and request for forgiveness consisted of minimizing her behavior (calling it a "joke," retweeting people who voiced support for her) and shifting the blame (on her use of Ambien) (Koblin 2018). Or we may consider the unapology of Astros baseball player, Yuli Gurriel, who in game 3 of the 2017 World Series, proceeded to make a "slanty eyes" facial gesture and mouth the word "Chinito" (Chinese person in Spanish slang) after he hit a home run off then-Dodgers pitcher Yu Darvish, who is of Japanese descent. While his later responses were far more conciliatory and apologetic, Gurriel's first comments on the incident, seemingly blamed Darvish ("If he feels offended, I want to apologize to him"), deferred responsibility ("I didn't mean to do anything offensive"), and pled ignorance ("I didn't know that was offensive to them"). ${ }^{3}$ The overwhelming conclusion one derives from such unapologies is: "I didn't intend to do it, so I'm not really at fault." But I suggest that intention is not all that matters. We are responsible for more than what we cognitively, premeditatively intend to do, a point that the growing body of knowledge of unconscious behaviors and implicit bias continues to clarify.

This paper will consider the philosophical work of Emmanuel Levinas and investigate how it converges with this concept of a personal political apology and of owning up to a responsibility that precedes, and is beyond, mere intention or individual action. I will begin with a rudimentary study of our colloquial usage of the term "apology," summarize Levinas's intriguing use of the term in his corpus, and then spend most of the essay considering how, and the degree to which, Levinas's thought can be constructive to the idea of a personal political apology.

Much has been made in Levinas scholarship regarding the concerns and difficulties related to translating Levinas's ethics into a politics, not to mention the observation that Levinas's texts offer little by way of how to address specific political issues. I, like many other scholars of his work, find Levinas's thought to be profoundly compelling and constructive, and yet there are also limitations in what his insights can offer us in the political sphere on their own. Specifically, I will suggest that his ahistorical, asymmetrical account of intersubjectivity is inadequate to explain what an apology can or seeks to achieve on a substantial political level. For this, I believe we must bring a Levinasian-inspired account of the self-other relation in conversation with other resources that will allow us to more adequately take into account both parties and better appreciate the concrete situation in which the need for apology arises.

\footnotetext{
My thanks to my friend and fellow Levinas scholar Eric Severson for inspiring this term. For an in-depth study of this kind of verbal maneuvering, see (Bailey 2015).

(Hoornstra 2017). For a more charitable reading of Gurriel's response, see (Boswell 2017).
} 


\section{A Working Definition and Structure of an Apology}

I begin with a working definition and phenomenological description of what we typically consider an apology. An apology, unlike apologetics, is not a defense or an excuse, but rather, is to say that I have no defenses or excuses for my actions. According to the Merriam-Webster's Dictionary, an apology is an "admission of error or discourtesy accompanied by an expression of regret." This definition alone reveals our modern propensity to focus solely on one's individual, intentional actions against another person. This definition can neither account for collective or corporate acts of confession, nor for one's (passive) complicity in unjust social structures. Yet it is helpful in that it suggests that the speech act includes an emotional valence and a recognition that the action being apologized for should not have happened. Conversely, if I say, “What I did was wrong, but I don't really feel bad about it, and I may well do the same thing again if I had the chance," then I'm not offering an apology.

We can add to this a phenomenological description of our lived experience of an apology. If Levinas's unconventional use of the term is to be of any significance, if it is to be of any help in our everyday lives, then it must be conversant with the concrete act of apology that we regularly enact. Now, I have two children, ages nine and six, respectively, so apologizing is a daily act in my home. When I walk through an apology with them-if I am patient enough to go through the entire process-it would appear that the act of an apology includes the following stages (I have utilized some classical Levinasian terms here, which will be further elucidated later on):

1. Encountering of the face: I want my child to look the other in the eye and enter into the humanity of the other.

2. Empathy: I want my child to imagine how they would feel if they had been the victim, to consider how they would respond if the same action had been done to them.

3. Admission of guilt to oneself: I want my child to understand that their action was hurtful, to admit what they did was wrong.

4. Taking responsibility and admission of guilt to the other: I want my child to express sorrow, to verbally admit they were in the wrong.

Many will stop there, but it seems like an apology is incomplete without two more steps:

5. Reconciliation: I want my child to ask, "Will you forgive me?"

6. Restitution/Reparations: I want my child to ask, "How can I make it better?" [At the very least, hug each other]

Admittedly, a number of concerns immediately come to mind. At the very outset, as I will discuss later, Levinas questions the power and necessity of empathy. And the ideas of reconciliation and restitution further complicate the matter. It could be argued that forgiveness is a more specific act, and carries with it more religious connotations, than the act of an apology. And then, there is the possibility that the other person chooses not to forgive, and Levinas, like several other Jewish thinkers writing after the Holocaust, suggests that some wrongs are so radically evil that forgiveness and restitution is impossible, especially on any kind of political or national level. ${ }^{4}$ However, I am hoping this brief sketch provides an adequate outline to have the gist of what is involved in an apology and will allow us to turn to Levinas's texts.

\section{Levinas's Use of "Apology"}

Levinas makes use of the term "apology" on numerous occasions. Here I will focus specifically on the various meanings of the term in Totality and Infinity and how he alters its meaning in Otherwise than Being. At times, Levinas's employment of the term is unique and nuanced, but often, his usage helps to clarify our colloquial understanding of the term.

4 See (Levinas 1989, pp. 146-48; Jankélévitch 2006; Wiesenthal 1998). 
Of the approximately 30 occurrences of "apology" in Totality and Infinity, it serves three (though possibly four) main functions. First, the very act of apology suggests a distinction between self and other. To apologize, I must differentiate myself-the wrongdoer-from the victim who is "infinitely distant from my own reality" (Levinas 1969, p. 40; see also p. 219). An apology implies a subject, a particular distinct from the other, and a "will," Levinas says, who must "be present at its trial" (ibid., p. 243).

Second, Levinas suggests that the entire structure of language takes the form of an apology. He writes, "The very fact of being in a conversation consists in recognizing in the Other a right over this egoism, and hence in justifying oneself. Apology, in which the I at the same time asserts itself and inclines before the transcendent, belongs to the essence of conversation" (Levinas 1969, p. 40; see also pp. 118-19). Speaking is not enacted in solipsistic isolation, but rather, in conversation with others. Thus, speaking is always already a response, a having-already-been-spoken-to. I speak because someone has already placed a demand upon me. Language itself, then, is structured as an ethical act. ${ }^{5}$ To speak is to account for oneself, to respond to the needs of the other. Speaking is premised on a hearing of the demands of the other, an excess of responsibility I can never fully account for.

Third, apology is thus what constitutes my very subjectivity, not as an autonomous egoism, but as a subject "called in question" as soon as this self arrives on the scene (Levinas 1969, p. 119). "Apology does not blindly affirm the self," Levinas writes, "but already appeals to the Other" (ibid., p. 252). Apology reveals the self not as independent but as integrally related to the other: responsibility precedes rights. My "infinite responsibility" to the other reveals my originary condition in an "apologetic position" (ibid., p. 245). Every drink I take or piece of food I eat implies an apology to those others who could have that nourishment instead of me (ibid., p. 293). Apology, thus, reveals in me a responsibility that grounds my subjectivity, a responsibility and election that I cannot trade with anyone else (ibid., p. 245). Apology is the name he gives for how my life, my very existence, is always already dependent on the lives and sacrifices of others.

All of these accounts of apology allude to a fourth use, or one that is perhaps interwoven within all of the others I have just detailed. On a couple of occasions, Levinas states that the "I is an apology" (Levinas 1969, p. 118) within the context of his discussion of the I whose identity is established "in enjoyment, in egoism, in happiness," and in solitude (ibid., p. 62; cf. pp. 118-19). We may understand this usage in the conventional Socratic sense: an apology as a defense or the act of "justifying oneself" (ibid., p. 40). But Levinas's point is that the act of justifying oneself is unjustifiable, for the very act itself already references the other (point 3 above) and is interrupted by the other (point 2 above). Justifying myself cannot get off the ground without illuminating the ethical obligation I have to the other. ${ }^{6}$

In Otherwise than Being, "apology" is used only four times. In his later works, Levinas preserves many of his earlier thoughts, yet he also works harder to articulate a denucleated and decentered subjectivity that is grounded in a "passivity more passive than all passivity" (Levinas 1998c, p. 14). Whereas in Totality and Infinity, the subject exists in enjoyment and desire, and apology reveals an ego with a will and a capacity to justify him or herself, in Otherwise than Being Levinas locates a

5 "The ethical presence is both other and imposes itself without violence. As the activity of reason commences with speech, the subject does not abdicate his unicity, but confirms his separation. He does not enter into his own discourse to disappear in it; it remains an apology ... it is language, that is, a response to the being who in a face speaks to the subject and tolerates only a personal response, that is, an ethical act" (Levinas 1969, p. 219).

6 Many thanks to an anonymous reviewer who helped tease out this point. There is one other use of apology I have bracketed. Levinas also depicts apology as a kind of protest against history, as the absence or silence that ruptures the history books written by the winners. History, Levinas says, "tend[s] to form a totality. It excludes the apology, which undoes the totality in inserting into it, at each instant, the unsurpassable, unencompassable present of its very subjectivity. The judgment at which the subjectivity is to remain apologetically present has to be made against the evidence of history ... The invisible must manifest itself if history is to lose its right to the last word" (Levinas 1969, p. 243). Here, apology seems to be the anti-history, a cry against Hegel's internal logic where everything that is, is as it should be. The invisible (apology) calls into question the visible. Apology is an act of "revolt" (ibid., p. 244). It is motivated by the "cry and protestation" of those who have been trampled by history, the "stranger, widow, and orphan" (ibid., p. 244). 
responsibility that precedes the positing of the ego, an obligation to an anarchic past that holds me hostage prior to any commitment, and prior to perceiving my questioner (ibid., pp. 102, 117). Hence, in the later work, apology is always too-little, too-late, always too substantial; apology reflects a reassertion of the self and is located on the side of the logos, in the said, in an act of freedom (ibid., pp. 102, 197). In contrast, Levinas wants to highlight a more preoriginary account of responsibility at work in me that is a "non-voluntary event of persecution" (ibid., p. 197), and which disqualifies any apology (ibid., p. 121). This responsibility leaves me obligated before I even have the chance to speak, before I even have the chance to make a claim for myself. It is a responsibility beyond being and prior to theory, which ruptures the identity of the ego and destabilizes every said.

The upshot of Levinas's account of responsibility is a decentered subjectivity, a self already called into question, that is obligated to an infinite responsibility for the other. Not only is my life an act of regret for how its very existence displaces the standing of the other, but prior to the possibility of apology, and prior to having heard the demands being asked of me, I am elected to an asymmetrical, nonreciprocal relation with the other where I perpetually have "one response more to give" (Levinas 1998c, p. 84) and am called to subject myself to a total offering of myself "without waiting for reciprocity" (Levinas 1985, p. 98). In my ethical enactment, the other remains at a position of height. On his account, the self "bears even responsibility for the persecuting by the persecutor" (Levinas 1998c, p. 75). The response of the other to me is the other's prerogative, and should I take it into account in my actions, I am no longer being ethical. The "demand of myself is not comparable with what I have the right to demand of the Other," which "indicates a metaphysical asymmetry" (Levinas 1969, p. 53). ${ }^{7}$

\section{Applying Levinas's Thought to Political Apology}

We can now turn to consider Levinas's quasi-phenomenological account of apology to the question of political apology, particularly the case at the outset where I am called into question by my Black coworker, called to accountability for the white supremacy at work throughout our political and social systems in America-and even my own body. There are at least three aspects of Levinas's account that are profoundly illuminating.

First, virtually all modern political theories are grounded in the preservation of the rights of the individual. The founding fathers of the United States, for example, claimed it was "self-evident" that all "men" (sic) have "certain unalienable Rights, that among these are Life, Liberty and the pursuit of Happiness," as the Declaration of Independence so famously utters. This account assumes at the outset an autonomous, self-subsisting subject, that a nation is a collection of individuals. This resonates with Sartre's account of radical freedom where "no limits to my freedom can be found except freedom itself" (Sartre 1992, p. 567). Levinas, in contrast, argues that freedom grounded in itself is arbitrary, and rather, that all individual freedom is preceded by a more originary passivity. Before I can be a being-for-itself, I am a subject born from another, subjected and responsible to another. Contra Sartre, I am not "condemned to freedom," but rather, "invested as freedom," which flows out of an originary responsibility to the other prior to freedom (Levinas 1969, p. 84). Justice is grounded in responsibility rather than freedom or rights.

The rights-based approach begins with an orientation toward myself and an attempt to protect my rights from those that might impinge upon them-whether other people or an authoritarian government. In contrast, the responsibility-based approach begins with an orientation toward others, toward asking myself what obligations or responsibilities I have toward others and my country. It does promote the right to life and liberty, but it is concerned with preserving the rights and liberties of others.

7 In support of this view, Levinas regularly draws from Dostoyevsky's The Brother's Karamazov to depict this total substitution of self for other when he quotes: "We are all responsible for all men before all, and I more than all the others" (Levinas 1985, p. 98; 1998c, p. 146; see also Levinas 1987, p. 108; 1989, p. 182). 
Rather than merely suggesting all citizens have individual wills that can choose to pursue life and liberty, the responsibility-based approach is compelled to ask what unjust systems exist that impede others' access to life and liberty, and it feels obligated to create just social systems that are equal for all.

Second, Levinas's preoriginary responsibility that decenters my subjectivity and precedes any consent to, or understanding of, a command (Levinas 1998c, p. 197) is an ample description of how I find myself called to account for the systemic, racist social structures that dominate American society. My present is built on the past, on a past history of oppression, exclusion, and marginalization of others. Prior to any choice, I was born into America, given American citizenship, and reaped the extensive benefits of my whiteness. Due to the long racist past of America, I was born into a context that afforded me a safe, suburban neighborhood, a well-financed (and almost entirely white) education, and the all-around acceptance and affirmation that comes with being a white, male, Christian of European descent. I was born into a context where, unlike people of color, no one questions my citizenship, my religious sincerity, or my capacity for virtue or patriotism. I did not earn this, I did not will it into existence. I cannot change this past, and yet I find myself responsible for it nonetheless, responsible for the ways in which it perpetually grants me opportunities that people of color cannot as easily obtain. The cries of injustice by those who have felt the underside of American empire contest me like an "exposure prior to consent" (Levinas 1998c, p. 122). Levinas's account of responsibility reveals me as vulnerable to the other, ruptured, decentered, unsutured. ${ }^{8}$

On this point, we find rich resonances between the goals of Jewish philosophy and that of African-American philosophy in their shared tonality as philosophies enacted from the underside of empire. In his seminal essay, "What is Jewish Philosophy?" Emil Fackenheim, a contemporary of Levinas, suggests that the task of Jewish philosophy in a post-Holocaust world is an ethical act of resistance, of remembrance, and of preserving Jewish identity against the possibility of annihilation. Jewish philosophy begins in a place of "rupture," of "the presence of an absence," Fackenheim says, an absence that recalls Auschwitz where even the bones of the victims were incinerated to dust (Fackenheim 1996, pp. 182, 183). Such a philosophical pursuit, then, is a practice "shot through with melancholy" (ibid., p. 182); it is a study motivated by wonder-as philosophy always has been-but a sense of wonder now "mingled with a new horror" (ibid., p. 183). It is why Levinas dedicates Otherwise than Being "To the memory of those who were closest among the six million assassinated by the National Socialists" (Levinas 1998c, p. v). Jewish philosophy is philosophy performed in a minor key, a dirge.

African-American philosophy begins in a similar melodic register, that of the blues. It is a "philosophy born of struggle" (Leonard Harris), an act of liberation (James Cone), an act of resistance against Whiteness. ${ }^{9}$ In that same tonality, George Yancy describes philosophy as "asking of us nothing less than to face both who we are and the world with as much honesty as we can manage, to grieve that world and to grieve our own mistakes within that world, and, yet, to be moved and transformed by the love of wisdom and the wisdom of love" (Yancy 2013, p. 7). Such a philosophical pursuit is grounded in bearing witness to the voices of marginalized people who have been silenced. Here, Yancy's honesty and grief resonate with Fackenheim's melancholy, but it also bears echoes of Levinas who writes, "Philosophy is the wisdom of love at the service of love" (Levinas 1998c, p. 162). In both the task of philosophy is a task higher than knowledge or being. Philosophy begins with the ethical call of the neighbor. Ethics precedes ontology.

Levinas claims that the basis of his account of a preoriginal responsibility that decenters the self is revealed most vividly through a phenomenological examination of breathing (Levinas 1998c, p. 181). It is in breathing, that most personal and vital of acts, that the innermost parts of my body are exposed

8 For an extensive analysis of this notion of "unsuturing" within the context of philosophy of race, see (Yancy 2016).

9 To add another voice from the margins here, it should be no surprise, then, that the first Latin American philosopher to discuss Levinas's work, Enrique Dussel, saw similar connections, in his books Ethics and the Theology of Liberation (1978) and Philosophy of Liberation (1985). 
to the other. Through breathing "there is exposure without assumption," the lung a cavity "hidden from perception" yet fully exposed to the unseen toxins and elements in the air. I am a breathing thing before I am a thinking thing: "all this signifies a subjectivity that suffers and offers itself before taking a foothold in being" (ibid., p. 180).

In breathing, we encounter the intervals between every breath, the gaps, the silences, the absences. In breathing, life meets death: "In human breathing, in its everyday equality, perhaps we have to already hear the breathlessness of an inspiration that paralyzes essence, that transpierces it with an inspiration by the other, an inspiration that is already expiration, that 'rends the soul'!' (Levinas 1998c, pp. 181-82). We hear here the double-meaning of "expiration"- -both to exhale and to expire. Yet in this mingling of life and death is an "inspiration," here again sensing the double-meaning of both breath and S/spirit- the same word for "breath" is the same word for Spirit in Hebrew (ruach), Greek (pneuma), and Latin (inspirata) — of the human and the divine revealed in the ordinary. The breathing other is a divine inspiration, it is the divine inspiration: love your neighbor, repair the world, do not kill me.

One cannot help but juxtapose this inspiration that is an expiration, this divine demand to infinite responsibility, with the continuous cries of the dying words of 43-year-old African-American Eric Garner. Eleven times, he cried, "I can't breathe" while a New York police officer choked him to death for selling individual cigarettes. Eleven times. Rhythmically, repetitively,

\section{I can't breathe/I can't breathe/I can't breathe}

I can't breathe/I can't breathe/I can't breathe

I can't breathe/I can't breathe/I can't breathe

I can't breathe/I can't breathe/...

Garner's psalm of lament ends drowned out by silence. Selah.

Reportedly, the police officers on scene did not attempt to perform CPR, did not seem to care if he breathed. ${ }^{10}$ The whole world is an inspiration, as everything breathes. But this is an inspiration mixed with horror. The pleas to aspire are aspirational, demanding us to the high calling of being human(e). Here, the demands levied against us from the transcendent yet desperate cry from "the stranger, the widow, and the orphan," the biblical motif that Levinas recalls (Levinas 1969, p. 77) resonates with every Emmett Till, Trayvon Martin, Eric Garner, and Antwon Rose whose blood cries out to us from the ground (Gen. 4:10). ${ }^{11}$ But the inspiration of the stranger, of the Black body with its hands up (don't shoot!), or stretched lifeless on the concrete, is an inspiration through asphyxiation, through suffocation. The air we breathe is air mixed with the final gasps that have arisen from gas chambers, from lynching ropes, from police chokeholds.

Third, Levinas's description of the other as infinite and radically other calls into suspicion the possible benefits of empathy. Empathy, conventionally understood, is regularly grounded in the ego and is knowledge-based. Typically, we describe empathy as an act of "putting myself in someone else's shoes." Theodor Lipps, who offered one of the earliest uses of the term "empathy" (Einfühlung), 12 essentially depicts it as a projection of myself into others. Lipps writes, "We must thus weave the other from the traits of our own personality" (Lipps 1903, p. 192). He describes empathy of the other as a duplication of the I, as an act of self-objectification (Zahavi 2014, p. 105), and as a "process of inner

10 Recalling Garner's final repetitive plea, George Yancy writes, "The cries of Eric Garner in Staten Island in 2014 constitute the clarion call of the suffering black male body.... What were the distorted assumptions, affective rigidities, and moral opacities that occluded the movement necessary for those white police officers to see/hear that Garner was in distress, struggling to breathe, to aspire?" (Yancy 2017, p. 593).

11 For Levinas's own usage of the story of the murder of Abel by his brother Cain, see (Levinas 1969, p. 232; 1998c, pp. 10, 117).

12 Before Lipps made use of empathy as a psychological phenomenon (or more recently, Martin Hoffman's use of empathy to trace stages in child development) and before Edith Stein and Husserl used Einfühlung as a term to depict how an alter ego who sees from the position of "there" is inherent within my perspectival vantage point of an ego who sees from "here," Robert Vischer used the notion of empathy in aesthetics to "describe how it is that we see into and feel the form of a work of art through perception" (Calcagno 2014, p. 30). 
imitation or inner resonance" that suggests sameness between self and other (Coplan and Goldie 2011, p. xii). Similarly, Melanie Klein writes, "Part of what we empathize with in the other derives from our own psychic material and fantasy: we recognize ourselves in the other."13 In sum, this account of empathy is grounded in the I, in the knowledge I have of myself, which is then transposed upon the other person. On this account, empathy is ultimately an annihilation of the uniqueness of the other and an assimilation of the other into the same. It is a circle that begins with the self, traverses out into the other, only to return safely back to the confines of the self. This account of empathy is grounded in epistemology, in (self-)knowledge. This is clear in how Allison Barnes and Paul Thagard define empathy as "the ability to comprehend another's state" or an "attempt to comprehend either positive or negative states of another" (Barnes and Thagard 1997; my emphasis). On this account, empathy is a simulative process whereby I utilize my own experiences and emotional states and conceptually map them onto the life of the other (ibid.). ${ }^{14}$

With this account in mind, I want to briefly turn to Janine Jones's essay, "The Impairment of Empathy in Goodwill Whites for African-Americans." Jones critiques well-meaning White people who seem incapable of seeing police brutality from the standpoint of people of color. Using the infamous Rodney King beating as her example, she stresses that the White jury failed to empathize with King, first, because empathy requires an analogical experience between self and other, where the empathizer believes "that the situation that the other is in is such that it is structurally similar to some situation that is really possible for him" (Jones 2004, p. 75), and second, because the jury was not motivated to work hard enough to imagine such structural similarities. If a White person "believes that it is conceptually impossible that he be in some situation $\mathrm{S}$ analogous to that of a black person," Jones continues, it is because the White person continues to be "thinking of herself under the concept of white" (ibid., p. 76). To this, she states that it would only take a couple seconds for a White person to empathize with Rodney King: if she simply imagined herself as Black. But since we don't, she concludes that the Rodney King case is "a shocking example of what can happen when a white person ... is motivated not to empathize with a black person" (ibid., p. 77).

I take no issue with Jones's claim that many White people simply are not motivated or do not want to empathize with the lives and circumstances of Black people. Many White people are simply unwilling to believe that racism still dramatically effects the lives of people of color in America. The outcry, resistance, and even vitriol against Black Lives Matter, Colin Kaepernick and other NFL players who kneel, and other movements centered around social injustices toward Black bodies make this painfully clear. However, her account of empathy reduces the ethical import of empathy to an epistemological category. This approach assumes we begin as autonomous subjects with an epistemological standpoint and then seek to arrive at an ethical knowledge of the other. In short, knowledge precedes action. But this reduction of the other to an object that I can comprehend, and the violence that proceeds from it, is precisely the basis of Levinas's entire critique of the history of Western philosophy and his proclamation that ethics is first philosophy. While Jones is right that empathy has its usefulness, and is absolutely right that most White people do too little to understand the world from the point of view of marginalized people, she fails to see that there are limits to the capacity of the imagination and even dangers to this priority of empathy as a form of conceptualizing the situation of the other person.

My concern—and this is Levinas's point—is not that we do not do enough—although, in some respects that is certainly true, given the incredibly low bar some White people use to claim they are not racist (e.g., "I'm not part of the KKK", "I've never used the N-word", "I voted for Obama!", "I have a Black friend"). Rather, the concern is that we goodwill Whites, equipped with our allegedly universal

13 Quoted in (Todd 2003, p. 54). Similarly, Diana Titjens Meyers writes that "sympathy as sharing in another's feelings and empathy as imaginatively reconstructing another's feelings" (quoted in Todd 2003, p. 50).

14 In fairness, Barnes and Thagard do acknowledge that "for many of us, empathy with the affective life of autistics will remain elusive" (Barnes and Thagard 1997). 
Kantian categories of knowledge, assume we can achieve far more than is actually possible in our attempts to empathize with people who have radically different histories and experiences as our own. ${ }^{15}$ To think that I can understand the suffering of another, particularly when I have never undergone that suffering, is to arrogantly totalize and reduce the suffering of the other to my own experience and to nullify the uniqueness of that other person's positionality in the world. Jones suggests that all it would take is two seconds to imagine myself as Black in order to empathize with Rodney King. But this assumes that I can imagine the entire facticity of the African-American experience, not to mention King's own unique history as a Black man living in Los Angeles, and instantly translate it onto my own embodiment in the same time it takes to take a breath.

Face to face with the pain and suffering of an embodied existence that is radically different than my own is where empathy falters. This is clearly one of the implications of Levinas's critique of theodicy in his essay "Useless Suffering," where, with the radical evil of the Holocaust in mind, he says that suffering is meaningless and defies rationalization. Suffering "renders impossible and odious every proposal and every thought that would explain it by the sins of those who have suffered or are dead" and the Holocaust speaks to "the outrage it would be for me to justify my neighbor's suffering" (Levinas 1998b, p. 98). Face to face with the incomprehensible suffering of the other, the most unethical thing I could do is to say that I can comprehend it, can provide a metaphysical explanation for it, or can tell someone I know how they feel. As Sharon Todd summarizes, “In Levinas's view, sympathy and other forms of feeling-with seem to support a mode of togetherness that is not patently ethical and in fact resembles ... a 'being-with.' Feeling with others cannot lead to transcendence, for it blurs the distinction between self and Other that Levinas is so adamant to maintain" (Todd 2003, p. 52). As a white male living in America I simply cannot discursively comprehend how a Black mother feels when she must give her teenage son "the talk," so that he is prepared, as much as is feasible, with behaviors that will (hopefully) minimize physical attack—or death—at the hands of the police. As a white male living in America, I have little comprehension of what it would mean to "put myself in the shoes" of someone who constantly lives in fear that the color of their skin will be the reason they do not get a job, are followed in a department store, or get pulled over by the police. "Walking while white" or "driving while white" simply have no signification in my every day being-in-the-world.

What is important here is to point out that despite this critique of an epistemologically based ethics, this does not mean we are rendered paralyzed and inert. For Levinas, sameness is not what compels me to act on behalf of the other, but radical foreignness. This means that ethical action may well precede epistemological understanding. ${ }^{16}$ Levinas articulates a moral standpoint that precedes and grounds knowledge. Levinas writes, "Obedience precedes any hearing of the command" (Levinas 1998c, p. 148), that is to say, the performance of the command (the saying) precedes my full comprehension of the content (the said) of the command. This does not mean that one ought to act naively or recklessly, but rather, it means that right knowledge does not necessarily lead to right action (e.g., rejecting the view that being or epistemology grounds ethics), but even more radically, that ethics precedes and conditions epistemology. As Richard Cohen puts it, "To know the good is already not to have done it. One does the good before knowing it—ethics lies in this 'before'" (Levinas 1985, p. 11).

Here Levinas alludes to Exodus 24 when Israel is receiving the Law. The people respond in unity, in a passage that is often translated as: "We will do everything the Lord has said; we will obey"

15 Jones seems to admit this in a comment relegated to a footnote in her paper: Putting ourselves in another's shoes "is misleading because it suggests that we are to put ourselves, with our histories and our stories, in someone else's situation (their shoes). But the idea is that we are to simulate others' minds by trying to understand how they are in their shoes. We do this by trying to find similarities between our histories and stories and those of the person with whom we are seeking to empathize in such a way that via the mapping of our experiences onto theirs, imagining ourselves in the other person's shoes would be to imagine that other person in his or her own shoes" (Jones 2004, p. 81n9).

16 Regarding the Holocaust, we find a very similar account of ethics in Elie Wiesel: "Sometimes I am asked if I know 'the response to Auschwitz'; I answer that not only do I not know it, but that I don't even know if a tragedy of this magnitude has a response. What I do know is that there is 'response' in responsibility. When we speak of this era of evil and darkness ... 'responsibility' is the key word" (Wiesel 2006, p. xv). 
(Exod. 24:7). But a more accurate translation is simply: "We will do and we will understand," or, "We will obey first; we will understand later." The rabbis understand this to mean two things: (1) it is a total commitment to God, to an obligation without knowing the full extent of what the commandment actually entails (Weisz 2002), and (2) ethics is performative: ethics is lived by doing it (Sacks 2016). ${ }^{17}$ We become ethical people not through knowledge but through ethical action.

I may not be able to comprehend or rationalize the suffering of the other, but I can-and must-bear witness ${ }^{18}$ to it and give it space to be heard (Levinas 1998c, p. 146). I bear witness to the unknowable voice that calls me to responsibility and act without knowing the full extent of my obligations. To this, Levinas also appeals to another theme in the Hebrew Scriptures for support. Even if we cannot comprehend the pain and suffering of others, we have an obligation to bear witness to their experiences and be present to hear their story. This is what Levinas means when he utilizes the phrase "Here am I" (ibid., p. 142). Abraham, Samuel, and Isaiah are called by an unrecognizable or indescribable voice, and expected to respond simply with "Here am I" (Gen. 22:1; 31:11; 1 Sam. 3; Isa. 6:8)—not with "I am here," a sentence that positions me as the subject in control, but rather, in the dative or the accusative (Levinas 1998c, p. 111), submitting to a call.

So then, opposed to the notion of empathy as a way of seeing myself in the other, which is an ethics of sameness, bearing witness, is an ethics borne out of irreducible difference. ${ }^{19}$ Rather than an ethics grounded in personal freedom or pure reason, this is an ethics borne out of vulnerability. The answer to the suffering of the other is not to explain it but to respond and become one who suffers on behalf of the suffering other. ${ }^{20}$ Ethics is an act of service, an act of sacrificial love that defies reason.

\section{The Limitations in Levinas's Account of Alterity and Apology}

Finally, I want to address what I think are the limitations of Levinas's account of apology within the context of systemic racism, which suggest we must look to other resources who might collaborate with Levinas for a solution to how we apologize for or mourn the prevalence of systemic injustice. Specifically, to the degree to which Levinas defends an abstract humanism as well as an entirely asymmetrical account of the self-other relation, which includes espousing the infinity of the other as beyond history and beyond culture, I believe this renders the goals of apology impossible and reveals weaknesses in Levinas's own comments about our encounters with others.

First, Levinas stresses that we encounter the other beyond history, culture, and aesthetics, for ethics is precisely what ruptures history, law, and art. There are merits to this maneuver, but by doing so, despite working hard to emphasize the materiality and fleshliness of responsibility, Levinas turns the other into an abstraction. He claims that the true meaningfulness of the encounter with the other occurs in "a situation that precedes culture ... in a gaze of man aiming at a man precisely as abstract man, disengaged from all culture" (Levinas 1998a, p. 101). Elsewhere, he describes the other as "one without a complexion" (Levinas 1998c, p. 49), as if the other were encountered without skin tones or facial features. In "Signature" (orig. 1976), Levinas reiterates that morality arises "in the quasi-abstract epiphany of the face, which is stripped of every quality—absolute-absolving itself

17 As Rabbi Lord Jonathan Sacks writes, "We can only understand Judaism by doing it, by performing the commands and living a Jewish life.... The modern Western mind tends to put things in the opposite order. We seek to understand what we are committing ourselves to before making the commitment. That is fine when what is at stake is signing a contract, buying a new mobile phone, or purchasing a subscription, but not when making a deep existential commitment. The only way to understand leadership is to lead. The only way to understand marriage is to get married" (Sacks 2016).

18 On this notion of bearing witness, see (Oliver 2001).

19 As Lingis explains in his introduction to Levinas, "This alterity is not simply that of an alter ego, parallel to though divergent from the ego that is me, and conceived through empathy. It is not conceived, comprehended, by varying the attributes I grasp in myself" (Lingis 1998, p. xiii). Elsewhere, he continues: "For Levinas this kinship, this fraternity of men is not rooted in the collaboration of a Mitsein, mediated through a world, dwelling-place for all, or through an objectivity constituted as common to all, nor in an intercorporeality constituted by perception and empathy, but is already ethical. My fellowman" (ibid., p. xxxn37).

20 Again, drawing from "Useless Suffering," Levinas says that ethics is precisely "the just suffering in me for the unjustifiable suffering of the other" (Levinas 1998b, p. 94). 
of cultures" (Levinas 1990, p. 294). In one interview, he says that "the best way of encountering the Other is not even to notice the color of his eyes!" (Levinas 1985, p. 85). And in another, here speaking explicitly about Black bodies, he states, "To have a relation to the face means that if one sees a Negro one does not pay attention to the color of his skin, nor to the color of his eyes" (Goud 2003, p. 31).

Levinas was imprisoned by Nazis in a prisoner of war camp where Jews were separated from other captured French soldiers and were subjected to harsher conditions and longer work days. Most of his family members were gunned down by Nazis. Given that he was personally excluded based on his physical traits and ethnic (and religious) identity, one can sympathize with Levinas's shift to the notion of colorblindness as a solution to the problem of discrimination and as a mode of approach by which we encounter the other as truly human. To exclude and exploit the other simply because of the color of one's eyes, the color of one's skin, or the shape of one's nose is certainly to deny the humanity of the other and to actively resist the sense of responsibility that is made manifest in the approach of the other person. However, Levinas's preference for the modern ideal of colorblindness is problematic, as it not only aligns with the deep-seated abstract, Eurocentric humanism that Levinas often criticized, but it rationalizes away the very kind of political apology that is stake.

Before I move on, it is also imperative to qualify the stated goals of Levinas's project. When Levinas speaks of ethics, he has in mind the face-to-face encounter with the other and brackets what he calls the "third party," the fact that I am not only responsible to one person but to "another, who is also a neighbor" (Levinas 1998c, p. 128; see also p. 83). The arrival of the third, Levinas says "is the birth of thought, consciousness, justice, and philosophy" (ibid., p. 128; cf. p. 157), and politics. The majority of Levinas's major works are spent articulating the face-to-face relation, and he seems content to leave the implications of his account for the arrival of the third (i.e., politics) up to his readers. This is important, not only so that we can treat Levinas's words charitably but to point out that, were Levinas explicitly asked what his ethics has to say about political issues of apology or systemic racism, we may have received a more nuanced response. Be that as it may, we are left with the writings of Levinas that we do have, and while the abstract other may function well enough in Levinas's ethics, there are at least three significant problems with utilizing colorblindness as a solution within the realm of politics:

(1) Colorblindness is at odds with what is revealed in our existential experience of the world. Even if we can show that biologically the notion of race does not exist and racism has no scientific basis, that is, that skin color has no genetic correlate that can be used to establish a sub-species within "human" or as a point of distinction between humans regarding their superior intellect, athletic prowess, or moral virtue ${ }^{21}$ that does not render the term meaningless. For even though the "evidence" and "conclusions" that were drawn out of pseudo-scientific studies of race (e.g., eugenics, neoteny, phrenology, steatopygia, and so on) have been shown to be the results of an a priori belief in the inferiority of Black bodies, this does not erase the fact that people of color have had to live within a social and cultural milieu wherein they have been constantly treated as inferior by these false assumptions. Stated otherwise, on the level of the political, we always encounter other humans within a meaningful social and cultural milieu-in particular, marginalized communities who have been discriminated to not interact with this social and cultural milieu as an abstract face.

To be clear, Levinas never endorses scientific racism; however, denying race as a socially and culturally meaningfully concept for our intersubjective encounters is only easy for those who are not negatively shaped by it. As a white person, I can espouse colorblindness about race because my race is rarely pointed out by others, and it is rarely used as a barometer to determine whether I am trustworthy or criminal, friendly or potentially violent, academically advanced or just a "diversity hire." 22 To deny color is to deny that Black bodies encounter the world differently and encounter the

21 For several criticisms of the history of scientific and pseudo-scientific racism, see (Yancy 2016, pp. 87-94; Dennis 1995; Graves 2003; Gould 1977, pp. 214-21).

22 The data bears this out. In the 2006 "Portraits of American Life Study" survey, they asked, "How often, if at all, do you think about or are you aware of what race you are?" Only $9.7 \%$ of those who identify as White responded that they think about 
gaze of the other differently, and to deny ethnicity is to disregard how the encounter with another culture can uniquely challenge us on the ethical level (Eisenstadt 2012, p. 51). As Sharon Rush puts it in her book about learning about race as a white mother of an adopted African-American daughter, "It is impossible for a Black child to see the world as a White child. To be Black necessarily is to interpret the world in a different way from the way a White child interprets it. Unlike the white child, the Black child struggles with the inner conflict created by notions like color-blindness" (Rush 2000, p. 57).

When people say, "I don't see color" - a common refrain by many of my white friends who insist they have never performed a racist act in their lives-perhaps what they mean is: "I believe in and live by Martin Luther King's 'dream' for a day when 'people will not be judged by the color of their skin, but by the content of their character.'" But one's good intentions, one's verbal assent to a list of abstract ideals, are not enough. In America, a country founded on white supremacy, chattel slavery, and the explicit exclusion of African-Americans from citizenship, ${ }^{23}$ one simply cannot not see color. Distinctions through color are taught to us, both explicitly and implicitly, and they are instilled in us throughout our entire lives. Whiteness is drilled into us as the assumed norm, as that which stands outside of diversity or difference, and everything else is viewed as a deviation of the norm (Yancy 2013). Whiteness is habituated into our ways of being in the world, which shapes us on the level of our unconscious behaviors, as the vast body of literature in implicit bias is now revealing to us. In this vein, George Yancy writes: "By the time White students have arrived in our classrooms, they have already been shaped by White ways of being-in-the-world, White ways of avoiding the issue of White privilege, White ways of constructing nonwhite bodies as 'different,' White ways of seeing themselves as 'innocent' of White racism, and White ways of taking up space and moving through that space in the capacity of ownership and possession" (Yancy 2014, p. 11).

If we conclude with Levinas that one ought to pay no attention to the color of a person's skin, although one's skin is precisely the basis for the cultural construction of racism, then there is essentially nothing here to apologize for when it comes to the historical reality and prevalence of systemic, institutionalized racism toward people of color. For a political apology to properly function, it must attend to the materiality of embodied subjects who live and move within culture where my apology is needed and to which it necessarily applies. Accounting for the color of the skin of my co-worker who accuses me of being complicit in the comforts of not being singled out by a particular political party's positions and policies is a necessary requirement for the political apology.

(2) Colorblindness, this admonition to exclude the physical traits of the other and reduce the other to an abstraction, is particularly at odds with Levinas's critique of empathy. On his critique of empathy, Levinas is emphatic that it is impossible for me to put myself in the shoes of another precisely because his or her lived experiences, unique exposure to pain and suffering, and historicity are radically different from my own. But to ignore the color of one's skin is to deny the physical basis upon which people of color experience discrimination, prejudice, and racist animosity. To ignore one's skin color entirely is to dismiss how one's epidermal pigmentation shapes how we are permitted or not permitted to navigate in a racist world, and thus, fundamentally shapes our lived experience. To ignore skin color would be to deny the reality of the other's suffering. My exposure to the radically unique suffering that is undergone by a Black body, which involves the undoing of his or her subjectivity, a suffering

their race every day, whereas $47.7 \%$ of African-Americans and $41.6 \%$ of the Hispanic/Latino population think about their race every day (Emerson and Sikkink 2006).

23 In the infamous Dred Scot v. Sanford supreme court case (1857), which was determined by a 7-2 decision, Justice Taney claimed in the majority opinion that "a free negro of the African race, whose ancestors were brought to this country and sold as slaves, is not a 'citizen' within the meaning of the Constitution of the United States. ... The only two clauses in the Constitution which point to this race, treat them as persons whom it was morally lawful to deal in as articles of property. ... Since the adoption of the Constitution of the United States, no state can by any subsequent law make a foreigner or any other description of person citizens of the United States, nor entitle them to the rights and privileges secured to citizens by that instrument" (Van Evrie 1860, I. lines 4-7, p. 4). 
that is completely foreign to my own lived experience, is precisely what resists my totalization of the other's difference into sameness.

(3) Colorblindness appears to be at the root of what we might describe to be Levinas's own unconscious or implicit bias, specifically the ways in which he seems to be blind to the Eurocentric cultural assumptions that shape his thought. This point is extremely important, for if Levinas is going to be of any value with regard to the issue of systemic racism, we must understand how the pervasive nature of systemic, institutionalized racism can take root in our lives, behaviors, and the very language that we use even without our cognitive awareness. Systemic racism is pretheoretical, preceding the arrival of the I. For example, in the context of anti-Black racism, in many European cultures, and especially in America, "black" and its connection to Black bodies, has regularly been associated with concepts such as "evil," "demonic,"24 "exotic," "irrational,"25 "violent," "irreflective," "criminal," animalistic, and so forth. Or we may consider the centuries-old, derogatory association of the Black body with the monkey, or as the missing link between the (white) human and the orangutan. Such terms and concepts, which are so deeply encoded in our collective memory, come fully loaded with symbolic meaning and cultural power when we take them up. They are bigger than us; they shape us. Levinas's account of language is actually quite instructive here: since language is learned by hearing the other, within an intersubjective structure by which I encounter the face other as a teacher in a position of height (Levinas 1969, pp. 204-6), then I cannot help but take up the culturally loaded connotations of that language I am given by encultured others when I utilize it.

Thus, despite Levinas's own admission to not see color, despite his claim that one encounters the face beyond culture and history, he appears to be unaware of the ways in which he sees the non-European other through the filter of Eurocentrism. This is particularly clear in the statements he makes about people from Africa. For example, in one interview, Levinas states, "The Bible and the Greeks present the only serious issues in human life; everything else is dancing.... There is no racism intended. ... Television shows the horrible things happening in South Africa. And there, when they bury people, they dance. ... It supplies us the expression of a dancing civilization; they weep differently" (Levinas 2001, p. 149). Only a few years later, Levinas repeats the same sentiment in another interview: "I often say, although it's a dangerous thing to say publicly, that humanity consists of the Bible and the Greeks. All the rest can be translated: all the rest—all the exotic-is dance" (Mortley 1991, p. 18).

The use of the word "exotic" here is particularly troubling, for it reveals the residue of Eurocentric assumptions that are embedded in his thought. As I've tried to stress, all of us are shaped by the cultural milieu in which we live and think, our language is loaded with social value as we take it up, and Levinas is no exception. So what is the best way to understand his use of this term? The use of "exotic" here to describe the Black body evokes a long, established history in French culture that was deeply embedded for well over 150 years before Levinas writes these words (Andreassen 2003; Yancy 2016, pp. 85-93; Berliner 2002). Throughout French culture at this time, to describe someone as "exotic" - a term reserved for non-Europeans-immediately implied someone who was primitive, radically foreign, hypersexual, rationally and morally inferior to Whites, animal-like, abnormal, savage, colored, and without the capacity to create civilization (Tator et al. 1998, pp. 75, 97; Berliner 2002, pp. 4-7; Andreassen 2003, p. 22; Yancy 2016, p. 87). Thus, we can surmise that the most logical

24 As early as John Cassian (360CE-435CE) the Christian monk, we find Christian theologians and mystics comparing black bodies to demons. In his Conferences, Cassian described the devil as "in the shape of a hideous Negro" and "like a Negro woman, ill-smelling and ugly" (Yancy 2016, p. xxxiv). Similarly, St. Theresa of Avila (1515-1582) says she knew she was being tormented by the devil because she "saw close beside me a most hideous little Negro gnashing his teeth. ... He made me thresh about with my body, head, and arms" (Theresa of Avila 2007, p. 222). It is the same term used to describe Michael Brown by the white police officer, Daren Wilson, who killed him.

25 While many examples of Europeans who depict people of Africa as ignorant and rationally inferior could be provided, most notably, in Levinas's own tradition, the great Jewish intellectual Moses Maimonides remarks, "The negroes in the distant south ... are like animals devoid of reason; in my view they are not to be classed as human beings" (Maimonides 1995, III.LI, p. 185). 
interpretation of Levinas's use of the same term includes at least some of these assumptions which were embedded in his cultural climate.

Further, "a racially influenced discourse helps determine what gets defined as 'great' literature, music, art, and what gets labelled as 'primitive', 'exotic', and so on" (Tator et al. 1998, p. 6), and this is precisely what we observe in Levinas. Another way to put it is that the language Levinas utilizes reveals the social or racial structure assumptions that are at work in his linguistic framework. So even though Levinas quite explicitly opposes the eugenics-motivated views of racism where biology determines one's moral or rational capacities-one need only read his early "Reflections on the Philosophy of Hitlerism" to observe that-the epistemic and cultural accounts of racism that permeated French culture at the time underlies his work. And the ways in which this cultural backdrop shapes his encounters with humans from other cultures cast doubt on his claim that one can actually encounter another person in a colorblind way. This is precisely what we observe when Levinas privileges the West, which he claims has a unique capacity for self-reflection, or self-critique, which makes the West "able to understand the particular cultures, which never understood themselves" (Levinas 1998a, p. 101). It is "the West," he says, that gives us "sciences, literature, plastic arts" and "philosophy" but "the rest is no more than local colour" (Levinas 1989, p. 285, my emphasis). According to Levinas, Judaism and the West embody "a great civilization. ... It is ... stripped of all local colour," however, "those civilizations labelled exotic ... can be easily distinguished from one another" (Levinas 1990, p. 52, my emphasis). How is it that Levinas can espouse colorblindness yet reduce African culture to "no more than local color"? Eisenstadt summarizes Bernasconi's analysis here: "The colorblindness of the subjective vision and the exaggerated claims for European civilization are sides of the same coin, such that the decolored face becomes the white face, the face of the normative, Western, European male" (Eisenstadt 2012, p. 51). In these further comments, whiteness is rendered invisible and the privileged European has allegedly developed the capacity to arrive at a view from nowhere, devoid of the influences of cultural bias. But Levinas views Black and Brown cultures as colored, as particular viewpoints, and as civilizations that are not great. ${ }^{26}$

All of this leads one to parse Levinas's quotations that reduce South Africans to a culture of "dance" with a new critical lens. His qualifiers to his statements raise troubling concerns. The comment "there is no racism intended," as Robert Bernasconi concludes in his meticulous essay on the matter, "serve[s] to confirm what it denies" (Bernasconi 2005, p. 16; Eisenstadt 2012, p. 47). And still more, that Levinas draws these conclusions of South Africans through mere observations that are handed to him by the technological gaze of the "television" - by the White, European newscasters and journalists who offer a caricatured version of South African life-not only suggests a noncritical reflection of how technology presents a curated, edited version of human experience, but it also evokes the infamous historical White gaze that viewed Black bodies in zoo and freak show exhibitions as a form of entertainment (Andreassen 2003). Through the lens of the television camera, the South African becomes "the exotic phantasm of the white imaginary" (Yancy 2016, p. 86). And as Tator, Henry, and Mattis point out, when art (in this case, African dance) is perceived through a racialized gaze, "What viewers see and hear is not reality itself, but reality refracted through the images, preconceptions, and attitudes that are part of their frame of reference. Each individual spectator's gaze on the 'other' is influenced by familiar narratives, allusions, and stereotypes that are part of his or her cultural experience"

26 The description of South African culture as exotic has led other Levinas scholars who find rich resources in Levinas's philosophy but reject the Eurocentric bias that is sometimes at work in his thought to conclude similarly. Sikka: "One cannot help noticing in Levinas's words here an unthinking complacency about his own cultural vantage point. ... He has carelessly assumed his culturally engendered givens." (Sikka 2001, p. 114). Bernasconi: "Levinas's privileging of Western culture, and specifically its capacity to understand other cultures, is at the expense of non-European or non-Western cultures" (Bernasconi 2005, p. 16). And Maldonado-Torres: "His view of the continuity between ancient empires and the 'fraternal West' reveals Levinas's ... inability to understand colonization in its own terms and with a genealogy of its own, delinked from the long Eurocentric scope of understanding Europe as a unity of sorts from ancient times to the present" (Maldonado-Torres 2012, p. 74). 
(Tator et al. 1998, p. 182). Again, this refraction is evident in Levinas's comments. Speaking of the "exotic" and "colored" civilizations, Levinas writes, "To the extent that they lose their 'curiosity' value, they find it increasingly difficult to define themselves" (Levinas 1990, p. 52). But who defines the Black body as a "curiosity" here? Who depicts their culture as "colored"? It is not the South African themselves, but the White, European gaze. Levinas seems to be channeling his mentor Edmund Husserl here, who echoed a similar sentiment. Alluding to the exhibitions and freak shows of Black and Brown bodies, Husserl writes similarly, "In the spiritual sense the English Dominions, the United States, etc., clearly belong to Europe, whereas the Eskimos or Indians presented as curiosities at fairs, or the Gypsies, who constantly wander about Europe, do not" (Husserl 1970, p. 273, my emphasis; Bernasconi 2005, p. 13). When Levinas and Husserl encounter the face of the non-European body, what they see is a cultured, colored face, one inscribed with the values that their own European culture has already assigned to it. Through this Western gaze, the Black bodies are interpellated, hailed as a "dancing civilization," while their own understanding of their identity is silenced, put under erasure.

The purpose of this intense focus on Levinas's mention of African people and African culture is not to discredit the entirety of his work-quite the contrary, given the extensive use of Levinas's powerful project throughout this essay, hopefully it is clear that my intent is to preserve the best parts of Levinas's thought which I believe are capable of being utilized to critique his weaknesses. It is, rather, to demonstrate how easily we can be thrown into and can perpetuate the structures of institutionalized racism. We ourselves are confronted with the sobering and humbling thought that if such an honorable person such as Levinas, someone whom I deeply admire and who so critically attacked the totalizing nature of Western ontology, could still be unaware of his Western, Eurocentric biases, how likely are we also to have been habituated into racist assumptions as well? ${ }^{27}$

Thus, one can simultaneously believe that Levinas is being sincere when he says he does not intend to be racist, and still demonstrate ways in which he-like us-is unconsciously participating in his society's stereotypes of other cultures. For this is precisely how systemic structures of racism work. Because whiteness is rendered invisible within this system, producing what Eduardo Bonilla-Silva famously calls a "racism without racists," a "color-blind racism" (Bonilla-Silva 2006, p. 2), one can be unaware of how one is privileging and reinforcing whiteness (ibid., p. 9). With this in mind, we can, thus, assess the ways in which support for the ideal of colorblindness regularly functions as a mechanism by which we can obfuscate, minimize, and even deny our complicity in systemic and institutionalized racism. "I don't see color" allows us to be unaware of the ways in which we draw on and perpetuate racist stereotypes unconsciously, even when that is not our desire or intent. "I don't see color" allows us to be unaware of the ways in which Whiteness functions as our perceptual and cultural norm and only treat others as colored or assume "diversity" to mean "non-White." "I don't see color" functions as a kind of verbal maneuvering that White people utilize in order to keep the discussion of race on the surface and in the abstract rather than to actively listen to the accusations of persons of color-who, as those marginalized and oppressed by racism, are usually in the best position to notice it—and self-reflectively evaluate one's actions and consider how race might play a role in them. "I don't see color" regularly stands alongside an assumption that racism may have been prevalent in the past but it is no longer a problem now in the present, as if one can extract one's present perceptual framework of reality from any influence of the history and factical givens that have shaped the world. It allows one to distance oneself from and wash his or her hands of the past racist acts of slavery, lynchings, and Jim Crow laws, and then willfully ignore how some of the White supremacist ideologies and assumptions that made such explicitly violent racist acts tolerable in American society still pervade the cultural milieu.

27 Again, to be fair to Levinas, it may be that he may suggest colorblindness as a function of ethics but may reject colorblindness on the level of justice. Consider, for example, the enigmatic line in Otherwise than Being that the "neighbor" is both "a unique face and in relationship with faces, which are visible in the concern for justice" (Levinas 1998c, p. 158). 
Second, Levinas's resistance to the concept of mutuality would seem to short-circuit the possibility and the process of apology. Levinas is adamant that in responsibility, "The intersubjective relation is a nonsymmetrical relation. In this sense, I am responsible for the Other without waiting for reciprocity, were I to die for it. Reciprocity is his affair. It is precisely insofar as the relationship between the Other and me is not reciprocal that I am subjection to the Other. ... The I always has one responsibility more than all the others" (Levinas 1985, pp. 98-99). Here, a number of aspects of Levinas's account of responsibility-and again reminding ourselves of his distinction between the face-to-face and the arrival of the third-are worth appreciating. Clearly, Levinas is speaking of an important resistance to reducing the self-other relation to an economic exchange, what he will define as "reciprocity" or a reversibility of self and other (such as in a handshake), throughout his texts (see Levinas 1998c, p. 83; 1985, p. 98). If ethics is merely a quid pro quo, if I scratch your back because you scratch mine, if I help you simply because it will help me get ahead, then it would seem that I have not performed any kind of virtuous act at all. Levinas's words resonate with the words attributed to Jesus in the Sermon on the Mount: "If you love those who love you, what reward will you get?" (Matt. 5:46 NIV). For Levinas, to welcome the other is to offer an act of hospitality without considering whether the other will be hospitable in return. If I personally apologize for institutional racism simply because I want to ensure that my Black friends know that I am one of the "good" Whites, then I have not actually offered an apology.

In the case of an apology, a Levinasian account of responsibility, based strictly on his ethics, would then suggest that an apology is demanded of me regardless of whether my apology is accepted, regardless of how the other will respond to my apology. This is especially constructive given the long history of the language of "racial reconciliation" 28 in the U.S. (often used in religious circles) where apologies come with the expectation that an apology alone is all that is needed to make amends (reparations being a priori excluded from the conversation), where reconciliation is really a veiled attempt at assimilating minorities into Whiteness, and where apologies assume that "both sides" have equally contributed to the broken relationship (similar false equivalences having been made by our current presidential administration between White Nationalists, on the one hand, and anarchists and members of Black Lives Matter, on the other). The nonsymmetry of Levinas's account of responsibility demands of us to take ownership for ourselves rather than point the finger at others.

Despite these merits, my primary concern is that Levinas's ethics/politics binary seemingly leaves us with two polar options: either, on the one hand, we have an entirely asymmetrical account of the intersubjective relationship that is marked by its "irreversibility," its "one-way relationship" (Levinas 1998c, p. 84), or on the other hand, we have a reciprocity that is "like reversibility of the two way road open to the circulation of information, where the direction is indifferent" (p. 96). Either there is an infinite obligation to the other (ethics), or there is the "closed circle of totality" (politics), which encompasses and assimilates the other within the order of the same or totality (Levinas 1969, p. 172). Numerous scholars have suggested a possible third way, that of mutuality, which cuts between the binary of irreversibility and reversibility, which seeks to retain the moral force of Levinas's asymmetric ethics but rejects the idea that recognizing the other's obligation for me amounts to a closure or totality. Mutuality, then, is more like a spiral or fold, which preserves difference within an interconnected web of relationship that remains perpetually open. ${ }^{29}$ Since a spiral never returns to its beginning

28 For a brief history and critique of this notion in Christian social justice circles, see (Hackett 2017).

29 For an extensive account of the self-other relation as a dialectical spiral, shaped by a synthesis of the accounts of intersubjectivity by Merleau-Ponty and Levinas, see (Bahler 2016, pp. 141-66). For an extremely illuminating account of the self-other relation as a fold, which is particularly influenced by Deleuze and Whitehead, but also the apophatic tradition, see (Keller 2015, pp. 168-95). Adriaan Peperak and Iris Marion-Young offer two other attempts at trying to articulate a third way in Levinas's thought. Peperzak, for his part, speaks of a "chiastic asymmetry" where "our equality originates in the dissimilarity of contrary demands" and self and other "are bound together by the chiasm of two identical but opposite inequalities" (Peperzak 2006, p. 50). Similarly, Iris Marion-Young depicts the self-other relation as an "asymmetrical reciprocity" where "the relation of self and other ... is specifically asymmetrical and irreversible, even though it is reciprocal" 
point, it retains Levinas's account of ethics as "not coming back in any form to its point of departure" (Levinas 1998c, p. 84) while opening up the possibility for mutual interaction of self and other.

Whereas the language of reciprocity and nonreciprocity seems to assume a Cartesian account of subjectivity, that is, that we are disparate subjects who then encounter one another within a field that functions as a zero-sum game, or at least, an encounter between opposing desires, ${ }^{30}$ a spiral or fold suggests that self and other are always already entangled, symbiotically interconnected, and that our interactions with one another create a surplus that further enhances and expands our sense of selfhood. In intersubjectivity as a dialectical spiral, our asymmetrical responsibilities to one another result in a mutual decentering that is life-giving and expansive. The chiasmic nature of spirals and folds, as Catherine Keller notes, allows for the simultaneity of difference and relation-rather than separation (Keller 2015, pp. 170, 191). Like the folded layers of origami artwork or an exquisitely crafted, many-layered puff pastry dough, the fold reimages the self-other relation as "a nonseparable difference, a relation of difference: the differential relation is not a resemblance or a similarity, not a slide toward sameness. But relation does require a repetition-a doubling, or fold, of the one in the other" (ibid., p. 177).

Ethically, within the imagery of a spiral or fold, both self and other sense a responsibility for one another. The responsibilities of self and other are chiastic, crisscrossing each other, enfolding each other. But these responsibilities are not identical, not totalized in the structure of sameness, for difference is maintained within the relation. This imagery, in my view, allows us to preserve both the asymmetry that Levinas envisions and the mutuality that is necessary for politics.

The political vision of the spiral or fold seems to resonate with Martin Luther King Jr.'s famous words from his "Letter from Birmingham Jail": "Injustice anywhere is a threat to justice everywhere. We are caught in an inescapable network of mutuality, tied in a single garment of destiny. Whatever affects one directly, affects all indirectly" (King 1964, p. 79). On this political vision, much like the use of ubuntu in South Africa, ${ }^{31}$ I can only reach my human potential if I am concerned with others reaching theirs, my humanhood is inextricably bound up with the humanity of the other; indeed my human potential exists within the backdrop of a community that raises me and nurtures me. My engagement with the other does not occur within a sterile environment or within a vacuum, but always already occurs within a milieu of sociality, community, and materiality. On this account, to utilize Levinas's terminology, there is no "arrival" of the third party, for the third party is already taken into account when I encounter the other person.

This account of mutuality is helpful in enhancing our understanding of the account of personal political apology I have been investigating throughout this essay, for it provides us a third way between the Hobbesian politics of war that Levinas opposed and the account Levinas offers, which calls for a completely asymmetrical, nonreciprocal relation to the other. This third way, which perhaps may be understood as a translation of Levinas's ethics into a politics, rejects the false binary of pure egoism or

because my obligations to you and perspective of you are not identical to the obligations and perspectives you have toward me (Marion-Young 1997, p. 351).

30 In this respect, I am suggesting that Levinas's path to solve the Hobbesian "war of each against all" or the Hegelian master-slave dialectic is simply to invert the hierarchy of the I-other relationship: rather than granting primacy to the $I$, the other is encountered in the dimension of height (but also in a place of need) and moral authority. On this account, there still seems to remain a residue of an oppositional relationship- the needs of the other require the sacrifice, come at the expense of, the self. Admittedly, in his later work, particularly Otherwise than Being, Levinas seems to be headed in this direction when he utilizes language that resonates with the imagery of mutuality, enfolding, and entanglement such as proximity, dehiscence, and skin (Levinas 1998c, pp. 84-85), and yet he retains a hard stance regarding the asymmetrical nature of the self-other relation. A similar project can be seen in the work of John Drabinski, for example, who reconfigures Levinas's ethics into a politics through a decolonialist reading of Levinas that puts him into conversation with the notion of the rhizome, made popular by Deleuze and Guattari but also utilized by Édouard Glissant, which allows us to reimagine a more nonhierarchical, more decentered, and more material account of intersubjectivity which both preserves difference and highlights our solidarity with others (Drabinski 2011, pp. 169-85).

31 In South Africa, the notion of $u b u n t u$, figured prominently in the Truth and Reconciliation Commission. In contrast to the modern ego, "I think; therefore, I am," ubuntu, implies that "I am because we are" (Tutu 1999, p. 31). 
pure selfishness, on the one hand, and pure self-sacrifice or infinite responsibility, on the other. For in the act of an apology, both my and my interlocutor's futures are implicated in the act of apology and in the other's response. The other person's response to my apology does matter, not just because I would like to receive the forgiveness that might absolve my guilt of satiate my regret, but also because of what kind of freedom might be afforded to the one who forgives and because of what kind of future possibilities might be created within society as a result. The extent of my responsibility is not just to say, "I'm sorry," or feel remorse or regret; rather, the demand is to become a better person and repair the relationship — which, admittedly, may be impossible in some cases—and that necessarily implies mutuality and interaction between self and other.

With this in mind, I return to the question of a personal political apology. How might Levinas's thought, combined with the asymmetrical mutuality envisioned through the imagery of a spiral or fold discussed above, help us reconsider the task of political apology? For starters, it may well be that what my interlocutor is looking for is not an apology at all. Perhaps my assumption to provide an apology itself reflects a failure to truly hear the demands of the other, especially if I expect an "I'm sorry" to fix centuries of injustice. Here is where my response-ability to the responsibility experienced in being called out and decentered by the other demands an active willingness to further listening, lowering my defenses, and being even more vulnerable. With this important caveat in mind, I offer a preliminary sketch of a reimagined reconstruction of a political apology, one that is perpetually unfinished and insufficient, given the precarious task of living in a society that continually perpetuates institutionalized and systematized injustice:

1. Encounter of the Face: I look the other in the eyes, eyes made of flesh and blood. I see your humanity. Your demand on me leaves me undone, unsutured.

2. Nonepistemological Empathy: I do not begin to believe that I know what you're going through. I have never had to walk in your shoes. I am not here to analyze your pain.

3. Listening/bearing witness: But I want to hear your story. Can you share what your experiences have been like? Before we go any further, I want you to have the floor and take up the space in the room that I've been hoarding.

4. Admission of guilt/asymmetrical responsibility: Despite my verbal affirmation that racism is wrong, despite my mental assent to equality, I continue to benefit from a system that was created to help me at your expense. I continue to participate in it, both in explicit and unconscious ways. I want to lament that reality with you. And maybe just sitting in silence together is what is most needed right now.

5. Taking responsibility: I am part of the problem. My complicity is wrong and unjust. I am sorry, though my feeling sorrowful is inadequate in and of itself.

6. Forgiveness/Mutuality: Forgive me or don't forgive me, we need each other. My humanity is wrapped up in your humanity. We have to work together.

7. Restitution/Reconciliation: The responsibility to fix this situation is mine and you want more than just an apology from me. And yet I feel stuck. It is unfair to expect you to tell me what to do yet simultaneously unjust for me to take up the White savior complex and think I can fix institutionalized racism. In this undecidability, I must act without knowing, a task fraught with failure, but hopeful of a justice to come.

This is the best sketch of a personal political apology I can offer, and yet it still seems to be incredibly weak, problematic, already too late. For one thing, it appears simplistic and reductionistic, as if the process of apology, forgiveness, and reconciliation could be reduced to a universal formula. Second, it still largely centers around the self: I am still talking, still directing the conversation, still reducing my ethical obligation to a logos. Despite these glaring issues, I end this essay here, unfinished and open to critique, for if anything, Levinas claimed that the demand of responsibility for the other is infinite, unending, unjustified, impossible. For those readers expecting this essay to provide some 
finality to the reality of systemic racism, or to the concerns around the practice of political apology, I cannot offer the last word. I'm sorry.

Funding: This research received no funding.

Acknowledgments: Some of this material was inspired and encouraged as a result of participation in the National Endowment for the Humanities (NEH) Summer Seminar for College \& University Teachers: "Emmanuel Levinas on Morality, Justice, and the Political" held at SUNY at Buffalo, Buffalo, NY, 17-21 July 2017. Any views, findings, conclusions, or recommendations expressed in this publication do not necessarily reflect those of the National Endowment for the Humanities.

Conflicts of Interest: The author declares no conflict of interest.

\section{References}

Andreassen, Rikke. 2003. The 'exotic' as mass entertainment: Denmark 1878-1909. Race E Class 45: 21-38.

Australian Government. 2018. National Sorry Day 2018. Available online: https://www.indigenous.gov.au/ news-and-media/announcements/national-sorry-day-2018 (accessed on 27 August 2018).

Bahler, Brock. 2016. Childlike Peace in Merleau-Ponty and Levinas: Intersubjectivity as Dialectical Spiral. Lanham: Lexington Books.

Bailey, Alison. 2015. White Talk as a Barrier to Understanding the Problem of Whiteness. In White Self-Criticality Beyond Anti-Racism: What Is It Like to Be a White Problem? Edited by George Yancy. Lanham: Lexington Books, pp. 37-57.

Barnes, Allison, and Paul Thagard. 1997. Empathy and Analogy. Dialogue: Canadian Philosophical Review 36: 705-20. [CrossRef]

Berliner, Brett A. 2002. Ambivalent Desire: The Exotic Black Other in Jazz-Age France. Amherst: University of Massachusetts Press.

Bernasconi, Robert. 2005. Who Is My Neighbor? Who Is the Other? Questioning the 'Generosity of Western Thought.'. In Emmanuel Levinas: Critical Assessment of Leading Philosophers. Volume IV: Beyond Levinas. Edited by Claire Elise Katz and Lara Trout. London: Routledge, pp. 5-30.

Bonilla-Silva, Eduardo. 2006. Racism without Racists: Color-Blind Racism and the Persistence of Racial Inequality in the United States. Lanham: Rowman \& Littlefield.

Boswell, Thomas. 2017. At World Series, a Racist Taunt Fuels a Stunning Episode of Civility. The Washington Post, October 28. Available online: https://www.washingtonpost.com/sports/at-world-series-a-racisttaunt-fuels-a-stunning-episode-of-civility/2017/10/28/93c5fa9a-bc1b-11e7-9e58-e6288544af98_story. html?utm_term=.993556260c23 (accessed on 15 May 2018).

Calcagno, Antonio. 2014. Lived Experience from the Inside Out. Pittsburgh: Duquesne University Press.

Coplan, Coplan, and Peter Goldie. 2011. Introduction. In Empathy: Philosophical and Psychological Perspectives. Edited by Amy Coplan and Peter Goldie. Oxford: Oxford University Press, pp. ix-xlvii.

Dennis, Rutledge M. 1995. Social Darwinism, Scientific Racism, and the Metaphysics of Race. Journal of Negro Education 64: 243-52. [CrossRef]

Drabinski, John. 2011. Levinas and the Postcolonial: Race, Nation, Other. Edinburgh: Edinburgh University Press.

Eisenstadt, Oona. 2012. Eurocentrism and Colorblindness. Levinas Studies 7: 43-62. [CrossRef]

Emerson, Michael O., and David Sikkink. 2006. Portraits of American Life Study, 1st Wave. Available online: http:/ / www.thearda.com/pals/codebook/analysis/Var1622.asp (accessed on 29 August 2017).

Fackenheim, Emil. 1996. What is Jewish Philosophy? Reflections on Athens, Jerusalem, and the Western Academy. In Jewish Philosophers and Jewish Philosophy. Edited by Michael Morgan. Bloomington: Indiana University Press, pp. $165-84$.

Goud, Johan F. 2003. 'What one asks of oneself, one asks of a saint': A Dialogue with Emmanuel Levinas, $1980-81$. Levinas Studies 3: 1-33. [CrossRef]

Gould, Stephen Jay. 1977. Ever Since Darwin. New York: W.W. Norton \& Co.

Graves, Joseph, Jr. 2003. Interview with Joseph Graves, Jr. Race-The Power of an Illusion. Available online: https://www.pbs.org/race/000_About/002_04-background-01-06.htm (accessed on 18 May 2018).

Hackett, Erna Kim. 2017. Stop Talking About Racial Reconciliation and Start Talking About White Supremacy. Faithfully Magazine, August 27. Available online: http://faithfullymagazine.com/talkingracial-reconciliation-white-supremacy / (accessed on 27 August 2018). 
Hoornstra, J. P. 2017. Astros' Yuli Gurriel Apologizes for Racist Gesture after Homer off Dodgers' Yu Darvish. The Orange County Register, October 27. Available online: https://www.ocregister.com/2017/10/27/ astros-yuli-gurriel-apologizes-for-racist-gesture-after-homer-off-dodgers-yu-darvish/ (accessed on 27 August 2018).

Husserl, Edmund. 1970. The Crisis of European Sciences and Transcendental Phenomenology. Translated by David Carr. Evanston: Northwestern University Press.

Jankélévitch, Vladimir. 2006. Forgiveness. Translated by Andrew Kelley. Chicago: University of Chicago Press. Jones, Janine. 2004. The Impairment of Empathy in Goodwill Whites for African-Americans. In What White Looks Like: African-American Philosophers on the Whiteness Question. Edited by George Yancy. New York: Routledge, pp. 65-86.

Keller, Catherine. 2015. Cloud of the Impossible: Negative Theology and Planetary Entanglement. New York: Columbia University Press.

King, Martin Luther, Jr. 1964. Letter from Birmingham Jail. In Why We Can't Wait. New York: Harper and Row, pp. 77-100.

Koblin, John. 2018. After Racist Tweet, Roseanne Barr's Show Is Canceled by ABC. The New York Times, May 29. Available online: https:/ / www.nytimes.com/2018/05/29/business/media/roseanne-barr-offensive-tweets. html (accessed on 31 August 2018).

Levinas, Emmanuel. 1969. Totality and Infinity. Translated by Alphonso Lingis. Pittsburgh: Duquesne University Press. Levinas, Emmanuel. 1985. Ethics and Infinity. Translated by Richard A. Cohen. Pittsburgh: Duquesne University Press. Levinas, Emmanuel. 1987. Time and the Other. Translated by Richard A. Cohen. Pittsburgh: Duquesne University Press. Levinas, Emmanuel. 1989. The Levinas Reader. Edited by Seán Hand. Oxford: Blackwell.

Levinas, Emmanuel. 1990. Difficult Freedom: Essays on Judaism. Translated by Seán Hand. Baltimore: Johns Hopkins University Press.

Levinas, Emmanuel. 1998a. Collected Philosophical Papers. Translated by Alphonso Lingis. Pittsburgh: Duquesne University Press.

Levinas, Emmanuel. 1998b. Entre Nous: Thinking-of-the-Other. Translated by Michael B. Smith. New York: Columbia University Press.

Levinas, Emmanuel. 1998c. Otherwise Than Being, or, Beyond Essence. Translated by Alphonso Lingis. Pittsburgh: Duquesne University Press.

Levinas, Emmanuel. 2001. Is It Righteous to Be? Interviews with Emmanuel Levinas. Edited by Jill Robbins. Stanford: Stanford University Press.

Lingis, Alphonso. 1998. Translator's Introduction. In Levinas, Collected Philosophical Papers. Translated by Alphonso Lingis. Pittsburgh: Duquesne University Press, pp. vii-xxxi.

Lipps, Theodor. 1903. Aesthetik. Hamburg: Voss Verlag, vol. 1.

Maimonides, Moses. 1995. The Guide of the Perplexed: An Abridged Edition. Translated by Chaim Rabin. Indianapolis: Hackett.

Maldonado-Torres, Nelson. 2012. Levinas's Hegemonic Identity Politics, Radical Philosophy, and the Unfinished Project of Decolonization. Levinas Studies 7: 63-94. [CrossRef]

Marion-Young, Iris. 1997. Asymmetrical Reciprocity: On Moral Respect, Wonder, and Enlarged Thought. Constellations 3: 340-63.

Mortley, Raoul. 1991. French Philosophers in Conversation. London: Routledge.

Nussbaum, Martha. 2013. Political Emotions: Why Love Matters for Justice. Cambridge: Belknap Press.

Oliver, Kelly. 2001. Witnessing: Beyond Recognition. Minneapolis: University of Minnesota Press.

Peperzak, Adriaan. 2006. Thinking: From Solitude to Dialogue and Contemplation. New York: Fordham University Press.

Rush, Sharon E. 2000. Loving Across the Color Line: A White Adoptive Mother Learns about Race. Lanham: Rowman \& Littlefield.

Sacks, Jonathan. Doing and Hearing (Mishpatim 5776). February 1, 2016. Available online: http:/ /rabbisacks.org/ doing-and-hearing-mishpatim-5776/ (accessed on 28 August 2018).

Sartre, Jean-Paul. 1992. Being and Nothingness. Translated by Hazel Barnes. New York: Washington Square Press. Slawson, Nicola. 2017. Dove Apologises for Ad Showing Black Woman Turning into White One. The Guardian, October 8. Available online: https: / /www.theguardian.com/world/2017/oct/08/dove-apologises-for-adshowing-black-woman-turning-into-white-one (accessed on 27 August 2018). 
Tator, Carol, Frances Henry, and Winston Mattis. 1998. Challenging Racism in the Arts: Case Studies of Controversy and Conflict. Toronto: University of Toronto Press.

Theresa of Avila. 2007. Interior Castle. Translated by E. Allison Peers. Mineola: Dover Publications.

Todd, Sharon. 2003. Learning from the Other: Levinas, Psychoanalysis, and Ethical Possibilities in Education. Albany: State University Press of New York.

Tutu, Desmond. 1999. No Future without Forgiveness. New York: Random House.

Van Evrie, J. H. 1860. The Dred Scott Decision: Opinion of Chief Justice Taney. New York: Van Evrie, Horton \& Co.

Weisz, Rabbi Noson. 2002. We Will Do and We Will Hear. May 14. Available online: http:/ /www.aish.com/h/sh/ se/48967001.html (accessed on 28 August 2018).

Wiesel, Elie. 2006. Night. Translated by Marion Wiesel. New York: Hill and Wang.

Wiesenthal, Simon. 1998. The Sunflower: On the Possibilities and Limits of Forgiveness. New York: Schocken Books.

Yancy, George. 2013. Introduction: Framing the Problem. In Christology and Whiteness: What Would Jesus Do? Edited by George Yancy. New York: Routledge, pp. 1-13.

Yancy, George. 2014. Introduction: White Crisis and the Value of Losing One's Way. In Exploring Race in Predominantly White Classrooms: Scholars of Color Reflect. Edited by George Yancy and Maria del Guadalupe Davidson. New York: Routledge, pp. 1-16.

Yancy, George. 2016. Black Bodies, White Gazes: The Continuing Significance of Race, 2nd ed. Lanham: Rowman \& Littlefield. Yancy, George. 2017. The Violent Weight of Whiteness: The Existential and Psychic Price Paid by Black Male Bodies. In The Oxford Handbook of Philosophy of Race. Edited by Naomi Zack. Oxford: Oxford University Press, pp. 587-97.

Zahavi, Dan. 2014. Self and Other: Exploring Subjectivity, Empathy, and Shame. Oxford: Oxford University Press.

(C) 2018 by the author. Licensee MDPI, Basel, Switzerland. This article is an open access article distributed under the terms and conditions of the Creative Commons Attribution (CC BY) license (http:/ / creativecommons.org/licenses/by/4.0/). 